\title{
Taustoitusta islamilaisuuteen
}

Marko Juntunen

Matkalla islamilaisessa Suomessa. Vastapaino. 228 s. 2020.

$\mathrm{M}$ arko Juntunen on kirjoittanut kirjan, joka on yhtä aikaa katsaus suomalaisen maahanmuuton kuin islamin kehitykseen ja nykytilanteeseen Suomessa. Kirja perustuu Juntusen laajaan tutkimustuotantoon, mutta on kirjoitettu kansantajuisesti. Lähdeluetteloon tutustumalla on mahdollista nähdä tutkimusten laajuutta ja kaarta. Kirjassaan Juntunen noudattaa tutkimusetiikasta tuttua anonymiteettiä. Vaikka hän tuo lukijan silmien eteen useita anekdootteja kohtaamistaan ihmisistä ja heidän henkilöhistoriastaan, on hän suojannut lähteensä tunnistamattomiksi. Henkilöhistoriat kietoutuvat mielenkiintoisella tavalla laajempaan historialliseen ja poliittiseen kontekstiin. Lukija saa muistutuksen siitä, mihin laajempiin yhteiskunnallisiin konteksteihin yksittäisten henkilöiden elämäntarinat nivoutuvat.

Kirja ammentaa tietonsa tapauskertomuksen," casen" kautta. Turun Varissuo on Suomi pienoiskoossa. Siellä Juntunen on tehnyt vuosia etnografista tutkimusta ja syventänyt käsitystään yhtä aikaa niin maahanmuutosta, islamilaisuudesta kuin lähiöistymisen historiastakin. Tutkimusprosessin aikana hänelle on syntynyt luottamuksellisia suhteita siellä asuviin ja työskenteleviin.

Islam Suomessa avautuu lukijalle moninaisena, jopa sisäisesti ristiriitaisena. Kahden pääsuuntauksen, shiialaisuuden ja sunnisuuntauksen lisäksi löytyy monenlaisia pienempiä ryhmittymiä ja suuntausta. Internetin ja sosiaalisen median aikakaudella on mahdollista hakea tietoa ylirajaisesti ja kysyä neuvoa uskonoppineilta eri maista, myös radikaalit näkemykset löytyvät helposti internetin välityksellä.

Pakolaisuuden historia Suomessa luo taustaa islamilaisuuteen Suomessa. Tässä kohdin kirjan ote tulee lähelle Heikki Hiilamon (2010) kirjaa Kuoleman listat (Otava). Vaikka varhaisimmat pakolaiset eivät olleetkaan muslimeja, heidän alkuvaiheidensa kuvaaminen taustoittaa suomalaisten suhtautumista 
muualta tulleisiin. Samalla myös käsitys pakolaisuuden syistä konkretisoituu. Pakolaisten saapuminen on synnyttänyt samantyylisiä vastustavia reaktioita aikaisemminkin. Varsinkin alkuvaiheen pakolaistyön strategiana oli kulttuuristaminen, jossa maahan muuttaneet pääsivät esille vain kulttuurinsa edustajina, siis kertomaan kulttuuristaan ja laittamaan oman maansa ruokaa. Näin yksilöt ja heidän moninaiset tapansa elää kulttuuriaan ja uskontoaan todeksi jäivät taka-alalle. Tämä elää sitkeästi vielä nykypäivän kulttuurien välisissä kohtaamisissa. Siksi onkin tärkeää, kysyä ihmiseltä itseltään, miten hän haluaa, että hänen kulttuurinsa ja uskontonsa huomioidaan.

Ulla Siirto 